\title{
Inquiry identity and science teacher professional development
}

\author{
Nadine Bryce $^{1} \cdot$ Sara E. D. Wilmes ${ }^{2}$ Marissa Bellino $^{3}$
}

Received: 13 January 2015/ Accepted: 16 November 2015

(C) Springer Science+Business Media Dordrecht 2016

\begin{abstract}
An effective inquiry-oriented science teacher possesses more than the skills of teaching through investigation. They must address philosophies, and ways of interacting as a member of a group of educators who value and practice science through inquiry. Professional development opportunities can support inquiry identity development, but most often they address teaching practices from limited cognitive perspectives, leaving unexplored the shifts in identity that may accompany teachers along their journey in becoming skilled in inquiry-oriented instruction. In this forum article, we envision Victoria Deneroff's argument that "professional development could be designed to facilitate reflexive transformation of identity within professional learning environments" (2013, p. 33). Instructional coaching, cogenerative dialogues, and online professional communities are discussed as ways to promote inquiry identity formation and collaboration in ways that empower and deepen science teachers' conversations related to personal and professional efficacy in the service of improved science teaching and learning.
\end{abstract}

Lead Editor: J. D. Adams.

Professional development in person: identity and the construction of teaching within a high school science department.

Nadine Bryce

nbryce@hunter.cuny.edu

Sara E. D. Wilmes

sara.wilmes@uni.lu

Marissa Bellino

mbellino@gc.cuny.edu

1 School of Education, Hunter College of the City University of New York, 695 Park Avenue, HW 903, New York, NY 10065, USA

2 Institute of Applied Educational Sciences, Université du Luxembourg, Campus Walferdange, Route de Diekirch, 7220 Walferdange, Luxembourg

3 Urban Education, The Graduate Center of the City University of New York, 365 Fifth Avenue, New York, NY 10016, USA 
Keywords Inquiry - Identity - Science education · Professional development · Community of practice

\section{Science teacher professional development and identity}

In this forum article we use Victoria Deneroff's ethnographic study (2013), which narrates the reflexive development of Marie Gonzales' inquiry science teacher identity, as a springboard to envision and explore how "professional development could be designed to facilitate reflexive transformation of identity within professional learning environments." Highlighting the overlapping and constituent nature of participation and membership in inquiry-based science teaching communities (Lave and Wenger 1991), our collaborative writing explores available research and personal experiences with including Inquiry Identity in inquiry-based science education teacher professional development. We discuss - at times, more in depth, and at times, in a more surface, playful way-the different ways this might be achieved. We are three colleagues with a range of professional experiences: a university-based teacher educator who teaches courses on and researches literacy in science for elementary and secondary students; a research specialist who investigates inquiry science learning in multilingual classrooms and who has more than 10 years of experience developing teacher professional development programs; and, an environmental and biology high school science teacher and researcher who engages students in authentic place-based science experiences. We do not present ourselves as case studies, but draw on our combined experiences and individual expertise to discuss how teacher Inquiry Identity might be integrated into teacher professional development to transform and promote communities of inquiry science teachers and learners.

Among a network of resources needed to support effective inquiry-based teaching and learning in science (e.g., teacher preparation, principal support and leadership, publicprivate partnerships), teacher professional development is paramount (Smith, Desimone, Zeidner, Dunn, Bhatt and Rumyantseva 2007). Inquiry teaching involves establishing a set of belief-driven practices grounded in theories and models of investigation, inquiry process skills, collaborative work, analysis and synthesis of results, and application of results to scientific arguments and explanations. Yet, April Luehmann argues that learning to teach through inquiry is more than learning a set of cognitive skills and activities. It involves developing an inquiry-oriented teacher identity that is social in nature, one that recognizes a teacher's "professional philosophy, passions, commitments, ways of acting, interacting, values and morals" (2007, p. 828). She proposes that professional development opportunities should not only provide experiences for teachers to become competent with practices of inquiry-based science instruction, but also create a cadre of professionals who recognize themselves, and each other, as members of a sociocultural group of educators who value and practice science through investigation and inquiry.

While exploring the nature of science teacher professional development, we examined literature on professional development for teachers in general, and science teachers, more specifically. Hilda Borko defined professional development as opportunities for teachers to "enhance their knowledge and develop new instructional practices" (2004, p. 3). Science teacher professional development that embraces inquiry contributes to a professional teaching identity when it provides a place and "safe space" (Luehmann 2007) for teachers to engage in ongoing reflection about a range of teaching practices and their roles as 
reform-minded practitioners. A sociocultural lens (Lave and Wenger 1991), when applied to this research, and as advocated for by Deneroff, assumes individual teachers are also learners who gain knowledge of teaching in multiple social (including informal) settings, classrooms, the school community, professional development courses and workshops. Teachers are "apprenticed" into communities that value, promote and practice inquiry, and as they learn these practices, take on identities and membership in larger social systems of a community of inquiry-based science teacher professionals.

\section{Professional development without attention to teaching identities}

Marissa: It is interesting to me that Borko pointed out that good professional development challenges teachers to learn more about the subject matter, students' thinking, and instructional practices. And, it is important that teachers participate in a network with other professionals. But I'm curious. Why, do you think, issues teachers face when exploring their professional identities are not examined?

Nadine: That is an interesting question. Other researchers who explore professional development of science teachers highlight the practice of teaching. For example, William Penuel, Barry Fishman, Ryoko Yamaguchi and Lawrence Gallagher (2007) examined the surveys of 454 elementary and middle school teachers to learn about the impact of professional development on their knowledge and implementation of an inquiry science program. Teachers reported that they needed time to plan, adapt, and implement inquiry activities into their curriculum in order for the professional development experiences to feel like a good "fit" between the curriculum and the demands placed on them. Teaching practice, not identity, has been used more often as a lens for addressing professional development.

Sara: One possible reason comes to mind. Over the past few decades, science education research in western contexts has increasingly embraced sociocultural ways of thinking about science education practices (De Jong 2007), including valuing sociocultural constructs such as teachers' identity development, and the use of inquiry-based instructional methods. At the same time, science education policy circles have made strong moves towards the standardization of inquiry-based science, the use of benchmarks, and defining quantifiable measures of "achievement" in science education (Tobin 2010). Through these policies, the push to "standardize" what counts as knowledge of a teacher's practice has, more often than not, been reduced to quantitative measures - think of itemized lists of benchmarks, and lists of what to look for during a lesson demonstrating "best practices" in inquiry-based science education. Thus, there exists a contradiction in research and policy. On one hand, the research community says sociocultural models of conceptualizing a teacher's practice are valuable, while policy circles are placing their money and efforts on standardization of "best practices." This is a question of values and where the money is flowing, not a question of changing models of "knowledge" as we understand it. As a result, how teacher professional development and teacher education have been developed, evaluated, and researched over the past few decades (Lawrenz and Desjardins 2012), in many cases, has resulted in the marginalization of approaches that embrace sociocultural models of teacher identity development, such as those advocated for by Luehmann. For example, colleagues who work in a large-sized school district in the northeast United States have described that, over the past 15 years, teacher professional development for math and 
science has increasingly been focused on topics, such as learning progressions and conceptual change, measures aimed at increasing students' performance on standardized tests.

Nadine: I see, Sara. Whereas research on science teacher professional development, and science teacher education more broadly, may advocate for inquiry-based instruction in classrooms, the emphasis appears to be on what is expected of any curriculum, to improve student achievement, often, as measured by standardized tests. As Penuel and his colleagues (2007) have written, more research is needed to establish the impact of professional development on teachers' practice, and student learning. It is worthwhile to pursue, but we are asking why teaching identity has been marginalized in that discussion, and what a shift in that discussion, from solely a focus on pedagogical content knowledge and curriculum implementation to a central focus on developing a professional identity focused on inquiry instruction, might do to build learning communities that will promote engagement and guidance for teachers who are working from an inquiry standpoint.

\section{Inquiry identity as a professional identity}

Sara: At the base of Deneroff's claim is the premise that pre-service and in-service professional development have been designed using cognitive paradigms, and "fail[ed] to consistently produce transformations of teaching practice" (this issue). In the envisioning we do in this forum, we propose ways in which the mediating role of identities and the contextualized nature of learning might be incorporated into the design of professional development and teacher education. But first, let us clarify what we think the relationship is between identity and professional development.

Nadine: In my review of literature on identity, several educational researchers and writers have posited that identity is a complex, multidimensional social construct that has been discussed and interpreted in myriad ways. Felicia Moore Mensah (2012) highlights the situational and negotiated aspects of identity, as the "kind of person" one is recognized to be in a given context. Similarly, Jean Lave and Etienne Wenger (1991) defined identity as "long-term living relations between persons and their place and participation in communities of practice" (p. 53). James Gee (2000) defined identity as a set of sociocultural and discursive practices that are recognized in conjunction with language (reading, writing, speaking, listening) and non-language activities (viewing, interpreting visually, valuing, interacting, using tools, symbols, and objects) carried out in situated contexts. This suggests a professional teacher identity, therefore, is a socially constituted "self" which is recognized by others, varied, and situated in interpretations and narratives of professional teaching practice.

Marissa: I had not done much thinking about teacher identity until recently when I read Luehmann's piece on reform-minded professional identity in science educators. Using this framework, I see my professional identity as complex and fluid, shifting with my current beliefs about the purpose of education, and science education. This belief is informed by my own assumptions about the possibility for young people to learn, the role of teachers, what I care about, what I know, and what I am confident with in the classroom, both in science content and my pedagogical style.

Sara: We can see these same characteristics of identity theory (Luehmann 2007) playing a role in Marie's Inquiry Identity formation, as well. For example, Marie's Inquiry Identity formed with the social support of administrators, mentors and different 
professional groups over the 10-year period that she participated in professional development communities.

Nadine: Deneroff illustrates the complex nature and social situatedness of an Inquiry Identity through Marie's story, and shares how teachers gain knowledge of science inquiry, both content and pedagogy, from a community of other inquiry teachers. According to Luehmann, there are limited professional development opportunities for inquiry-based instruction because science is most often taught through the transmission model of learning (e.g., lecture, demonstration and use of textbooks). Pre-service science teacher candidates who do not experience inquiry while student teaching often do not "buy in" to the inquirybased approach, and experience a disconnect between the recommended theory-driven inquiry practices and the transmission-based teaching and learning experiences they found successful as learners (Luehmann 2007). In a study of 6 pre-service secondary science teachers' use of inquiry during student teaching, Mark Windschitl (2003) learned that those who used inquiry most were not more reflective, or more aware of an authentic concept of inquiry, but those who had significant undergraduate or professional research science experiences. If a sociocultural lens was applied to this research, pre-service teachers who were familiar with practices of carrying out inquiry and investigations would also be viewed as participating members of a larger community of school-based and professional inquiry science practitioners, and potentially, resources for apprenticing novice pre-service teachers into that community.

Marissa: I think back on my own experience as a pre-service teacher in an alternative teacher certification program. While I know this experience is unique, I do believe there are many teachers with a similar background, especially in urban schools. Since I did not receive mentoring during student teaching, I personally did not see anyone demonstrating inquiry instruction. And, now, as a teacher with 10 years of experience, much of my teaching involves students doing authentic research, something I identify as true inquiry.

Nadine: Teaching science through inquiry is a major goal of science education today, but teachers must understand the goals and concepts of inquiry themselves before they can teach it. And, like you Marissa, many pre-service science teachers have little experience carrying out inquiry during their undergraduate courses or in authentic research contexts (Windschitl 2003). So, how did you get to practice inquiry-based science teaching in this way?

Marissa: There were networking opportunities, professional development experiences, and structural resources that allowed me to leverage knowledge gained from professional development in my school. Once I saw students asking their own questions and learning the skills and thinking of science, I was definitely convinced about using inquiry to create an engaging learning environment.

Sara: Once you became convinced, how were you able to find ways to sustain this type of teaching? What was it that supported this part of your identity as a teacher who values involving students in doing authentic research?

Marissa: I had the support from administrators in my school who allowed me to teach classes that were more inquiry focused, providing underutilized space in the school to develop a molecular laboratory, and by participating in professional development opportunities at a local university that connected me to like-minded science educators and doctoral students in science. I collaborated on grant writing to get funding for the research program, which continued the support my administrators provided. These opportunities created the physical space for the emergence of authentic research, but it was the interest generated by the students that has sustained the research program. Students brought their interests, experience, and knowledge of foods, pests, and wildlife, asking questions about 
mislabeling of fish in local markets, diversity of bed bugs found in different geographic locations, and illegal trade of seahorses. Using DNA barcoding techniques, students were free to investigate these inquires using novel molecular techniques and protocols they designed themselves. These investigations were truly authentic inquiry and looked and felt very different than the typical science lab activity. Students had ownership over the lab space and could be found making gels for gel electrophoresis or prepping samples for a DNA extraction during out of class time. Seeing students engage in these practices of science along with the continued support of a professional community of scientists and science educators contributed to my own reflexivity in teaching, reinforcing my Inquiry Identity.

Nadine: Marissa, the structural, economic and practical support you received from administrators, and professional development opportunities with university faculty and doctoral students were critical, because they provided you the "safe space and place" Luehmann identified as critical to launching and exploring inquiry teaching in your science classes. Luehmann's model of science teacher professional development moves beyond the acquisition of a set of cognitive skills, to one that recognizes the need for teachers to:

1. Develop confidence in their emerging competence with inquiry-based instruction;

2. Reconcile their existing beliefs and values about science teaching practice based on their experience as learners with theory-based inquiry practices explored in teacher preparation programs;

3. Locate themselves within larger social and political groups in schools, including stakeholders, administrators, parents and children; and,

4. Navigate varied theories and practices of science education, as well as interests that may conflict with perceived purposes of schooling (transmission vs. inquiry practices).

Sara: Marissa, there is much here that resonated with your development of inquirybased teaching, especially in the context of professional development opportunities with other teachers, and your work with multiple stakeholders, including administrators and students. In many ways, these experiences appear to have contributed to your evolving Inquiry Identity. What would it take for science education as a field to move in this direction?

Marissa: When I first started teaching, I went to every professional development opportunity that involved either science and/or environmental education. I loved going and being a part of a learning community, participating in professional, inquiry-based conversations, sharing ideas and imagining opportunities for my students. Most helpful in these professional developments was the sharing of practices and ideas. We had time and space to engage in an inquiry activity together and then share the ways this could work with students. That time to reflect on our own teaching situation (e.g. students, space, materials, time) was invaluable as it allowed me to strategize with a group of like-minded educators how to make this work in my teaching context. However, we did not always have time for reflection and collaborative planning. Without it, I would go back to my classroom with little space to enact what I had learned. This happened more than once and it left me feeling despondent at the lack of opportunities I was able to create for my students within an already tightly regimented curriculum.

Nadine: As Mensah (2012) has highlighted, as you were developing a situated, negotiated Inquiry Identity in your professional collegial community, the conflict of not being able to carry out inquiry practices in your classroom must have been frustrating and discouraging. How did you manage your desire to develop engaging instruction more aligned with the practice of science while meeting science standards and assessments? 
Marissa: I chose carefully. We were bombarded each day in our e-mails with professional development opportunities. Not all of them were useful. Now, I only participate in experiences I know I can directly use for my practice, that will foster my Inquiry Identity. Truthfully, I find that many experiences appear as if a large sum of money has been given to an organization to roll out some novel, inquiry-activity, and while the lessons are tied to standards, the activities are material intensive and therefore not possible. Or, they seem so separate from the curriculum that they become these discrete activities that students do not connect to the larger course goals. Just recently, a chemistry teacher attended a professional development session, and she came back and handed me a jar of pond water. She asked if I could use it in my class since she did not have the time to incorporate it into her curriculum.

Nadine: Windschitl (2003) reminded us that there are several different levels of inquiry that can be implemented in K-12 settings, from more teacher-directed to more studentdirected experiences: activities that confirm known scientific principles; structured investigations that proceed through pre-determined steps; guided inquiry in which learners develop models to investigate a problem posed by the teacher; and, open inquiry, in which learners design and carry out their own investigations. Marissa, I'm curious about what kind of inquiry you were expected to carry out with the pond water, since you did not go to the professional development experience yourself, but were only given the "materials." Have either of you had any powerful professional development opportunities that aligned teaching practices and goals for student learning with an Inquiry Identity?

Sara: I heard about a professional development experience run by the Exploratorium in San Francisco that offered teachers a week-long inquiry experience. They explored light in many different ways through the use of simple tools, but the focus was on the process, on the interactions, on asking questions and exploring. At the end, there were no "materials" to bring home. It was the process, thoughts, and interactions that were collectively shared during the inquiry process that mattered.

Marissa: The most valuable professional development $I$ have been involved in was the NSF GK-12 program, because it created a community of scientists and educators all talking and working towards the best ways to engage students with authentic science research. We created what Lave and Wenger (1991) described as a community of practice, a place where we collectively shared experiences and gained knowledge. I worked closely with other science teachers as well as doctoral students from a variety of disciplines, including molecular ecology, environmental psychology, and geography. Bringing our collective experience and knowledge to the task of creating an "authentic research module," we learned from one another, sharing pedagogical philosophies as well as content knowledge. Many of the authentic research modules that were developed started with the interest and knowledge of students, where their experiences were privileged. Students who worked within these courses were exposed to science content as it relates to their lives, including investigations into food and food systems, household cleaners, and local ecology. The resources that we brought to one another were invaluable as neither of us alone could have accomplished the creation of new inquiry curriculum modules without the support and knowledge of the larger group. Having been involved with the program for 4 years, I can say that the relationships and professional conversations established there have radically mediated my teaching and were what made this professional development opportunity unique. I now find myself continually looking for spaces to create communities of science teachers, educators, researchers, and scientists with similar inquiry values.

Sara: Just as Lave and Wenger (1991) proposed, the development of your teaching identity among other inquiry-oriented science teachers became long-term relations 
between individuals, your place and your practice as members of a community. Your experience highlights the essential role supportive communities play for teachers when they are working to implement new teaching methods and develop new identities. Unfortunately, the reality of working within schools, school systems, and often within short-term funded projects, means that projects often struggle to support the long-term development of communities. Teachers change schools, principals change positions, required curricula and assessment systems change, and funding periods are limited. In addition, in order to develop the type of community Marissa talks about experiencing and that also helped support Marie on her way to developing an Inquiry Identity (Deneroff, this issue) requires that teachers are invested in and want to work as a member of the community. This is not always the case in schools, districts, or education systems where teachers are being told it is mandatory to implement inquiry. This is an important consideration. Are teachers required to participate in professional development to gain credits or are they volunteering because they want to adopt a new teaching style?

Nadine: Sara and Marissa, without personal experience teaching or engaging in professional development in science education, I turned to the literature for perspective. Current education reform efforts to incorporate interactive, hands-on inquiry activities in school science have been characterized as essential for helping children learn and better understand the nature of science and how it is done (AAAS 1989, 1993; NRC 2000). But Deneroff reminds us to situate teachers' practice and children's scientific learning within a larger framework that anchors daily classroom practice in a social network of professional science organizations, and practitioners.

Marissa: I have found that this is difficult to achieve on a larger scale. At the individual level, yes, I see myself as someone who embraces an Inquiry Identity, but as much as we know this kind of learning benefits students, it seems to be a great challenge to move past the individual teacher towards the creation of a community of inquiry science teachers.

Nadine: This is the heart of the issue, Marissa. Elizabeth Davis, Debra Petish and Julie Smithey (2006) affirmed that explicit attention to identity as a part of professional development experiences can empower teachers and deepen their conversation related to personal and professional efficacy. And, Luehmann and Liz Tinelli (2008) posited, in a study of 15 secondary science teachers' participation in an online community to support their development of reform-minded practices, that identity "foregrounds the personal and multifaceted nature of learning in this profession" (p. 324). Without using an identity framework, Carla Johnson and Sherry Marx (2009) presented an urban science professional development model designed to promote change in teaching practices for middle school science teachers who worked predominantly with children from low-income communities and diverse language and cultural backgrounds. They implemented a long-term professional development experience to align instructional practices with professional science education standards, and transform the learning environments into more effective educational settings by engaging children in cooperative learning, questioning, and inquiry. Teachers appreciated opportunities to build relationships with each other through monthly group meetings, and to learn from and help each other through inter-class observations. But without an emphasis on identity as outlined by Gee, Mensah or Luehmann, Johnson and Marx left implicit and unexplored the personal and professional shifts in commitments, values, and ways of acting and interacting (Luehmann 2007) with each other and students that were critical to making some of the observed changes in teaching practices.

Sara: This brings us back to our charge as presented by Deneroff. How can professional development be crafted so that teacher identity is attended to? 
Marissa: Your question challenges all of us, Sara. I often feel that piecemeal interventions like cooperative learning and questioning strategies, as inquiry-based practices, will only be effective if teachers believe these interventions work. In other words, the Inquiry Identity and the inquiry strategy each presuppose the other. The educator with an Inquiry Identity will be more open to introduce and prioritize inquiry strategies while at the same time the inquiry strategies, if successful, might begin to move a teacher towards the more "inquiry end" of the identity spectrum.

Nadine: Perhaps, Marissa, the colleague that offered you the pond water after her professional development experience may have been challenged to make time to carry out inquiry experiences because there was a lack of conversation and professional network of school staff (teachers, administrators), members of professional science organizations, and/ or professional developers to support guided and open inquiry. "I realize that curriculum that offers no opportunities for fundamental shifts in teaching practice, that limits inquiry to an "add on" of hands-on activities, loses the point made by researchers Judith Ramaley, Barbara Olds and Janice Earle (2005), and the newly charted directions of education and research at the NSF." And, several questions arise: if research and professional development opportunities in the field are shifting in support of inquiry-oriented science (Ramaley, Olds and Earle 2005), has this shift embodied greater efforts to do more than teach teachers how to carry out inquiry activities with students? How can teachers encourage children to examine information and scientific phenomena from the standpoint of those leaders in the field who advocate for a pedagogy that presents controversies and conflicting arguments that shape what counts as knowledge in science? And, how do these conversations address (and construct) science teacher identities?

Marissa: Nadine, I think you raise a lot of important questions that do not have very clear answers, especially in relation to the ways teachers are prepared. Teacher preparation is not happening in ways that encourage teachers to challenge what counts as science. I do think these kinds of conversations help to form and shape teacher identity but if these conversations are not happening, and no one is challenging what counts as science, then we are just reproducing the same kinds of science teachers who do not value inquiry or only value it as a means to a prescribed endpoint. Part of the problem, based on my experience, is that teachers are not exposed to education research in their professional development, nor do I feel as if it is expected of teachers to engage with education research. It was not until I started my doctoral program that I began to see how so much of my teaching practice is informed by education research, and yet, looking to the research for guidance was never encouraged while teaching. I would almost argue that teachers are subtly discouraged from using research to guide their practice (unless it is prescribed by the district), and there is little, if any education research that is presented in professional development. It is almost as if the conversations that you are referring to Nadine, are happening, just not necessarily in schools; they are happening in academia. I am also very interested to see what is going to happen in science professional development around the Next Generation Science Standards (2013).

\section{Professional development, new standards, and identity}

Marissa: I attended a professional development session recently that began to address the newly released standards, and we were presented with a generic overview of how they are different from the previous standards with a focus on college readiness and cross-cutting 
concepts. I wanted to understand the research that suggests these ways of teaching science will benefit me and my students. An understanding of the research coupled with the time and space to imagine how to achieve these standards are crucial to internalizing these standards into our practice, and in turn, our professional identities.

Sara: Or, could this be a lack of connection between the entire school system you are working within, including the support you are given (or not given) to implement the standards, the assessment methods your system values, and the types of training you are (or are not) given to help you implement the new standards?

Marissa: Honestly, I believe there is very little overarching support within education to help teachers understand how best to implement the new science standards and how the standards will be aligned to current and future assessments for students and teachers. While the opportunities to learn more exist for some, they are not accessed by all, and in turn standards seem top-down and professional development seems piecemeal and farcical. By reflecting on my journey of becoming a more reform-minded science educator, I began to realize exactly what Nadine mentioned above, that some recommended practices that are called "inquiry-based science" are just increased access to hands-on activities and materials. For me, inquiry was not about the activities, but conversations with other teachers as we discussed what it really meant to teach students about science as a process, not science as content.

Sara: So, while participating in professional development, you were given space within your professional community to reflect on and discuss the process of science teaching (Borko 2004). Were you also given the space to reflect on your identity as well?

Marissa: I was thinking more about time. Deneroff stated that it took Marie a really long time, almost 10 years, to truly embrace an Inquiry Identity that felt comfortable to her. Time is a luxury that is often not granted in many professional development experiences. Most tend to be 1- or 2-day workshops that are not about building a community of learners who can engage in conversations about professional identity. Our expectations are that professional development will have instant impact on teachers' lives. I just do not believe that is how change happens, especially, if like Deneroff hopes, we are trying to shift the paradigm of science teaching and learning towards inquiry.

Sara: To synthesize the salient points that seem to rise up out of our collective experience, to incorporate identity into the design and practices of professional development would be to consider the teacher as an individual who holds beliefs, knowledge and attitudes, who performs in socially connected spaces. Supports must be long-term, and by this we call upon the field of science education to redefine what we mean by "long-term." In our experience, and in Deneroff's work, we see that we need to think on larger time scales. Marie reflects on 10 years of experience and how she formed an Inquiry Identity. To think that change can and will happen in 1, 2, or 3 years goes against what our work has shown is essential in supporting teacher change, and what has been illustrated in Marie's case.

Nadine: Like Deneroff, Luehmann noted that space and time to reflect on practice and communicate about research and practice connections are key elements of science teacher professional development. Teachers need opportunities to develop relationships that foster reflection on reform-minded practice, and an exploration of research. They need opportunities that consider their identities as members of professional learning communities that promote their participation and recognition as competent, contributing members of groups promoting reform-based science teaching (Luehmann and Tinelli 2008). Coaching may be a viable method for the professional development of science teachers. Sally Heineke (2013) examined language used during coaching experiences to support teachers' 
professional learning. While used often for literacy professionals in schools, instructional coaching can be an innovative and beneficial professional development model for science teachers because coaches are on-site mentors who can support active teaching and reflection on practices from a reform-minded perspective.

Marissa: I am really drawn to the idea of coaching as a model for professional development that truly supports individual teachers. I would say that my GK-12 professional development was the closest to this, but instead of coaching, it was the idea of partnering with a scientist (doctoral student in CUNY) in the classroom to support the gaps in my knowledge and bring in the actual skills that are used by a variety of scientists (for me, ecologists, molecular and evolutionary biologists, as well as environmental psychologists). Partnering with these individuals allowed me to build my own knowledge of these fields and challenged me to incorporate more research practices (e.g., inquiry and authentic research) in the classroom.

Sara: As both a participant and provider of science professional development, situations that were the most "successful" in supporting inquiry teaching and learning employed components of coaching. When I first taught middle school science, our school district offered a mentoring program for new teachers. My mentor was a senior member of our school's science department, and a strong supporter of inquiry science instruction. She attended external professional development opportunities and had over 15 years of experience implementing inquiry in her classroom. She also played the role of "liaison" to the district science and curricula personnel, and in this role, organized opportunities for the entire department to dialogue about our vision and goals for our teaching and students' learning. Not everyone agreed that inquiry was the best way to teach students, but even so, we all found ways to work together. During my first few years of teaching, my mentor provided me with material support, instructional support, and most importantly, emotional support. Later in my teaching career, I became a mentor for the e-Mentoring for Student Success (eMSS) program developed through the New Teacher Center at the University of California, Santa Cruz. The key feature of this program was an online interactive community forum where we, as mentors, would help mentees establish and work through action research plans to support their science teaching. This program was built on many of the characteristics you mention above Nadine, except it was not situated within a school. We worked to create strong online communities and had a series of researched-based support practices that we used to establish supportive, trust-based communities. Within both of these "coaching" situations, on one hand within the school, and on the other hand within an online community of teachers who never met face-to-face, there were opportunities for coaches to model instruction, for members to plan together and offer critique and support. Both models embodied the "communities of practice" concept (Lave and Wenger 1991). Learning about inquiry happened through participation in a community supported by a coach/mentor and provided space for members of these communities to "construct identities in relation to these communities" (Wenger 1998, p. 4).

Nadine: Coaches model instruction, plan with teachers, observe and offer critique and support, and are sources of instructional and professional support. Practically, a coach can mentor all the science teachers in a school, and build long-term relationships that can address practices, values, and goals of professional development. Coaches and teachers can build space for identity work through creating a community of professionals at one school site. There is no assumption here that teachers would immediately adopt professional development practices, goals, and values, but it would provide a context for mobilizing efforts that could address professional development from a standpoint of looking at teachers' work and subjectivities while engaging in reform-minded science teaching. 
Sara: What was not present for me in the coaching communities I experienced was an explicit discussion of, or reflection on, one's identity as an inquiry teacher. I can see now that they were communities that valued sociocultural ways of supporting identity formation, but identity formation and the conflicts it sometimes causes one on the path of development, were not explicitly discussed. There were no explicit opportunities built into the structures to explore questions like, "Who am I as a teacher and how do I fit in with this group?" If those questions arose, they were not planned.

Nadine: It is certain that within this work, there is a possibility for teachers and coaches to engage in authentic teacher research on reform-minded science practice. Unpacking current research, in the context of ongoing teacher professional development that recognizes the situated and contextual nature of teaching practice, would be important work for a community of science practitioners at a school site. But conducting research on their own teaching practice by examining instruction, student engagement, and student achievement in science, would be important for advancing student learning, and supporting professional teacher identity work.

Another related effort to continue an ongoing conversation among teachers and professional developers is to provide social media networking, like blogging, to increase communication and provide a "space" for reflecting on teaching practice, supporting ongoing teacher inquiry around reform-minded practice, and a place for providing a supportive opportunity to participate in the discourse of reform-minded science teaching. Again, this would contribute to community building and teacher reflection on practice, fostering a "community of practice" in which identity work is constitutive and crucial.

Marissa: Once I finish my doctoral work at CUNY in Urban Education, I would love to imagine a place where I did this kind of work with teachers in classrooms and schools. I want to incorporate both research and teaching young people. A lot of the research that we are exposed to in schools comes from the Department of Education and is selected specifically because it supports the larger education reforms that we are seeing (Common Core, Next Generation Science Standards). I think it is important to incorporate and empower teachers to do research in their classrooms. I am currently working at Brooklyn College, CUNY, with teachers on their action research projects to complete their graduate studies, and while this is not formally professional development, it is in many ways, since these are in-service teachers (2nd year NYC Teaching Fellows). The collaboration that we have created in this space supports these new teachers' awareness of their identities emerging from conducting research in their own classrooms. I have talked with many of them about some of the embedded assumptions they have about young people, their fears about straying too far from the curriculum as it has traditionally been taught, and their ways of shifting teaching away from transmission models of education. Even their research projects highlight their stance as science educators who privilege a quantitative approach to research. As I have worked with some of them, they have seen the value of a more sociocultural framework for thinking about research and this has been exciting. I see them struggling with issues of conflicting ideas and identities as they conduct their research and I think this speaks to the shifting identities that teachers go through as they learn more about their students and their practice.

Sara: Now that I have stopped to reflect on these past experiences I wonder, why is this coaching/mentoring model not more prevalent in teaching communities? Why are these types of teaching communities not sustained over time? Or maybe they are, but we have not explored how to use them to support Inquiry Identity formation. 


\section{The next generation of professional development}

Nadine: While some of the "next generation" professional development series may take a common prescriptive approach that neglects teachers' input, there are other successful models of science teacher professional development that could reflect, and respond to the situated needs of teachers in their particular district- and school-level teaching and learning contexts. From a sociocultural perspective, the importance of establishing a professional community within which individual teachers can explore their knowledge of content and instructional practices is central. According to Borko, well designed systems of professional development include "...activities and materials for teachers, descriptions of facilitator roles, and teacher outcome measures" (2004, p. 10). Penuel and colleagues (2007) similarly identified elements of effective science teacher professional development, including: localized, curriculum-linked, inquiry-oriented instructional approaches and materials; long-term collaborative support for teachers to implement curriculum; and, collective participation of teachers working alongside colleagues from the same schools and districts.

Sara: Nadine, this makes me think of the use of cogenerative dialogues to engage teachers and students, or teachers and cooperating teachers, in conversations around successful teaching. In short, cogenerative dialogues are meetings at which participants in a process (in this case, teachers, coaches, others involved in the professional development process) engage in a discussion about how the process is unfolding. Arising from the work of Kenneth Tobin and Wolff-Michael Roth (2005), this discussion provides a way for all participants to have a voice in the process. In making this space, cogenerative dialogues support the use of inquiry-based science in classrooms and influence teachers' identity formation (Siry and Lara 2012).

A second successful form of professional development that we are currently using engages teachers in discussions early on from the initial planning stages, in ways that help developers incorporate teachers' instructional and school-level needs into the planning process, before the science components of the professional development "begin." This allows us to bring in the voices and needs of the teachers we work with at the school and district level, while working within a national-level directive to disseminate inquiry-based science education. While these are just two of several successful models, they clearly point us in the direction of models "next generation" professional developers might use to work with teachers in ways that are supportive of them as professionals, responsive to their contexts, and provide space for the development of their identities as inquiry teachers.

Marissa: I have spent some time looking at the NGSS, and while at the time of this writing, only 15 states have adopted them, it does seem that they are being heavily endorsed by NSTA and other scientific and business organizations and communities. And while I believe there is a lot that is valuable in them, particularly the science practices and crosscutting concepts, I do believe that they continue to privilege what is being taught as opposed to how it is being taught. This makes me question whether these new standards will continue to reproduce the idea that science is a discipline where facts are privileged, as opposed to the processes of inquiry, which is much messier, more difficult to teach in the sense that you can not predict what your students will bring into the classroom, and harder to assess using traditional standardized testing. And if this is the framework that drives what we know about science, I do not know how these standards will help develop teachers with an Inquiry Identity. 
Sara: Marissa, I think you make a very important point, and I agree that I do not think the NGSS are in a position to, by themselves, mediate teacher Inquiry identity. It will be in the way that the NGSS are implemented and used as a tool by states, districts, and schools that will determine their impact on science education - both what is taught and how it is taught, as was the case with the science education standards released in 1996 (NRC). How they will be used and how they mediate teacher Inquiry Identity will remain to be seen. I think the NGSS certainly leave room for a teacher to develop a strong Inquiry Identity, if the teacher is also provided with the space, resources, and support to do so, but simply the creation and adoption of NGSS will not make this happen. To turn the conversation toward how the NGSS could assist a teacher in developing an Inquiry Identity, I have shared two examples of professional development tools and/or programs that provide spaces and support for teachers to develop an Inquiry Identity above-cogenerative dialogues and planning WITH teachers (as compared to externally determined professional development). Additional ways that professional development might reflect the groundwork laid out in the NGSS, and founded in sociocultural theories of teacher identity formation, might include what you, Marissa and Nadine, have mentioned before:

- Individual and group reflections,

- Coaching or mentoring,

- The formation of professional learning communities, and

- Opportunities to experience inquiry.

Nadine: Yes, Sara, you have summarized characteristics of science teacher professional development programs that would offer teachers opportunities to explicitly support awareness and development an Inquiry Identity. Now, through this dialogue, I have come to see that teacher identity cannot be envisioned as all inquiry-based or all traditional. Promoting inquiry-based science teaching and learning through professional development must respond to the need to focus on student achievement, as you noted earlier. Bhaskar Upadhyay (2009a) studied Daisy's work as an elementary science teacher who engaged in inquiry with children from low socio-economic and diverse ethnic and linguistic communities. The school's desire to get children to pass high-stakes standardized tests was pushed up against Daisy's desire to offer instruction that engaged children in inquiry and experiential learning. While Bhaskar Upadhyay (2009b) calls for examining teacher identity longitudinally to see the change of adapting and accommodating newly adopted teaching identities, Stephen Ritchie (2009) recognized multiple (and sometimes competing) identities that can be foregrounded and backgrounded in a situated view of the teaching and learning. In another body of work, he and fellow researchers, Ritchie, Tobin, Roth, and Cristobal Carambo (2007), suggested teachers transform old identities as they accommodate old and new identities in situated contexts. Ultimately, we must see this transformation of teachers' identities in support of improved student learning. Deneroff pushes for pedagogy that re-imagines students as active learners who can lead and navigate inquiry-based instruction in science.

Marissa: Absolutely. Inquiry-based professional development for science teachers should be focused on transforming student learning.

Sara: And, to do that Marissa, we learned how Deneroff invited Marie to share her voice on her development as an Inquiry Teacher, heeding Upadhyay's (2009b) call to researchers to bring in the voices of teachers to share not only who teachers say they are, but to highlight what they do for students. Professional development should explicitly address the identity of teachers and how teachers' identities impact children's developing identities as science learners. 
Nadine: And, consider that NGSS, with its more explicit definition on what counts as "inquiry-based practice," expands current emphasis on exploration and scientific investigation of the natural world (National Research Council [NRC], 1996, 2000), to include key concepts that cut across disciplinary domains within science, English Language arts, literacy and mathematics. These standards push us to recognize the unique needs of children and youth from diverse backgrounds (e.g., cultural, racial, ethnic, linguistic, socioeconomic, ability/disability, gender) who will be engaging in scientific study in schools, to increase learning opportunities and address challenges that may impede achievement in science.

Sara: Science teaching is principle-driven practice and as such, creates a means for identifying oneself as a specific type/kind/of teacher, who is recognized by self and others (Luehmann 2007). Because of the social nature of professional development, and science teaching, science teacher professional development can benefit from explicit attention to align school science, research, and practice in the learning sciences (National Research Council [NRC] 1996, 2000; NGSS 2013). The recent release of the NGSS, we hope, will prompt renewed efforts to support inquiry science instruction and learning in schools. Those of us who work with pre-service and in-service teachers need to find creative ways to provide time, a safe place, and space (Luehmann 2007) to allow teachers to discuss and wrestle with their multifarious and evolving identities in the face of competing agendas, but in the context of supportive professional communities of practice. Instructional coaching, cogenerative dialogues and online professional communities may serve these important roles.

Nadine: From a situated sociocultural view of science teacher professional development, our dialogue, collective experiences, and reflection on recent research suggests more flexible, collaborative, long-term models of professional development. Linking professional development activities to localized curriculum that promotes inquiry-oriented activities aligned to science standards and assessments, improves teaching and learning opportunities, while promoting inquiry teacher identity development. We have learned that a major goal of science teacher professional development is to provide support and opportunities for individual teachers to work together in organized groups to plan and reflect on a flexible implementation of inquiry instruction, perhaps through long-term discursive models of coaching (Heineke 2013) where individual teachers are paired with more experienced mentor teachers or science professionals, or through opportunities for cogenerative dialogues about successful teaching between and among colleagues (Siry and Lara 2012), or through online discursive communities that plan and reflect on inquiry practice (Luehmann and Tinelli 2008). What emerges promises to support teachers' identities and professional practice in service of improved science teaching and student learning.

\section{References}

American Association for the Advancement of Science. (1989). Science for all Americans. New York: Oxford University Press.

American Association for the Advancement of Science. (1993). Benchmarks for science literacy. New York: Oxford University Press.

Borko, H. (2004). Professional development and teacher learning: mapping the terrain. Educational Researcher, 33(8), 3-15. doi:10.3102/0013189X033008003. 
Davis, E. A., Petish, D., \& Smithey, J. (2006). Challenges new science teachers face. Review of Educational Research, 76(4), 607-651. doi:10.3102/00346543076004607.

De Jong, O. (2007). Trends in western science curricula and science education research: A bird's eye view. Journal of Baltic Science Education, 6(1), 15-22.

Deneroff, V. (2013). Professional development in person: Identity and the construction of teaching within a high school science department. Cultural Studies of Science Education,. doi:10.1007/s11422-0139546-z.

Gee, J. P. (2000). Identity as an analytic lens for research in education. Review of Research in Education, 25, 99-125. doi:10.2307/1167322.

Heineke, S. F. (2013). Coaching discourse: Supporting teachers' professional learning. The Elementary School Journal, 113(3), 409-433. doi:10.1086/668767.

Johnson, C. C., \& Marx, S. (2009). Transformative professional development: A model for urban science education reform. Journal of Science Teacher Education, 20, 113-134. doi:10.1007/s10972-009-9127-x.

Lave, J., \& Wenger, E. (1991). Situated learning: Legitimate peripheral participation. Cambridge: Cambridge University Press.

Lawrenz, F., \& Desjardins, C. D. (2012). Trends in US Government-Funded Multisite K-12 Science Program Evaluation. In Second international handbook of science education (pp. 723-734). Netherlands: Springer.

Luehmann, A. L. (2007). Identity development as a lens to science teacher preparation. Science Education, 91(5), 822-829. doi:10.1002/sce.20209.

Luehmann, A. L., \& Tinelli, L. (2008). Teacher professional identity development with social networking technologies: Learning reform through blogging. Educational Media International, 45(4), 323-333. doi:10.1080/09523980802573263.

Mensah, F. M. (2012). Positional identity as a lens for connecting elementary preservice teachers to teaching in urban classrooms. In M. Varelas (Ed.), Identity construction and science education research: Learning, teaching, and being in multiple contexts (pp. 105-121). The Netherlands: Sense Publishers. doi:10.1007/978-94-6209-043-9_8.

National Research Council. (2000). Inquiry and the National Science Education Standards: A guide for teaching and learning. Washington, DC: National Academy of Sciences.

National Research Council. (1996). National science education standards. Washington, DC: National Academy Press.

NQSS Consortium of Lead States. (2013). Next generation science standards: By states, for states. Washington, DC: National Academy Press.

Penuel, W. R., Fishman, B. J., Yamaguchi, R., \& Gallagher, L. P. (2007). What makes professional development effective? Strategies that foster curriculum implementation. American Educational Research Journal, 44(4), 921-958. doi:10.3102/0002831207308221.

Ramaley, J. A., Olds, B. M., \& Earle, J. (2005). Becoming a learning organization: New directions in science education research at the National Science Foundation. Journal of Science Education and Technology, 14(2), 173-189. doi:10.1007/s10956-005-4420-8.

Ritchie, S. M. (2009). Looking for daisy: Constructing teacher identities. Cultural Studies of Science Education, 4(3), 595-599. doi:10.1007/s11422-008-9172-3.

Ritchie, S. M., Tobin, K., Roth, W.-M., \& Carambo, C. (2007). Transforming an academy through the enactment of collective curriculum leadership. Journal of Curriculum Studies, 39(2), 151-175. doi:10. $1080 / 00220270600914850$.

Roth, W.-M., \& Tobin, K. (2004). Cogenerative dialoguing and metaloguing: Reflexivity of processes and genres. Forum Qualitative Sozialforschung/Forum: Qualitative Social Research, 5(3), Art. 7.

Siry, C., \& Lara, J. (2012). "I didn't know water could be so messy": Coteaching in elementary teacher education and the production of identity for a new teacher of science. Cultural Studies of Science Education, 7(1), 1-30. doi:10.1007/s11422-011-9339-1.

Smith, T. M., Desimone, L. M., Zeidner, T. L., Dunn, A. C., Bhatt, M., \& Rumyantseva, N. L. (2007). Inquiry-oriented instruction in science: Who teaches that way? Educational Evaluation and Policy Analysis, 29(3), 169-199. doi:10.3102/0162373707306025.

Tobin, K. (2010). Global reproduction and transformation of science education. Cultural Studies of Science Education, 6(1), 127-142. doi:10.1007/s11422-010-9293-3.

Tobin, K., \& Roth, W.-M. (2005). Coteaching/cogenerative dialoguing in an urban science teacher preparation program. In W.-M. Roth \& K. Tobin (Eds.), Teaching together, learning together (pp. 59-77). New York: Peter Lang.

Upadhyay, B. (2009a). Negotiating identity and science teaching in a high-stakes testing environment: An elementary teacher's perceptions. Cultural Studies of Science Education, 4(3), 569-586. doi:10.1007/ s11422-008-9170-5. 
Upadhyay, B. (2009b). Narratives, choices, alienation, and identity: Learning from an elementary science teacher. Cultural Studies of Science Education, 4(3), 601-610. doi:10.1007/s11422-008-9169-y.

Wenger, E. (1998). Communities of practice. Cambridge, MA: Cambridge University Press. doi:10.1017/ cbo9780511803932.

Windschitl, M. (2003). Inquiry projects in science teacher education: What can investigative experiences reveal about teacher thinking and eventual classroom practice? Science Education, 87(1), 112-143. doi:10.1002/sce.10044.

Nadine Bryce is Associate Professor of Literacy Education and teaches in the Childhood Education program and the Graduate Program in Literacy Education at Hunter College of the City University of New York. Her research focuses on literacy teacher education, literacy pedagogy in the content areas, and arts integration across the curriculum. Her recent publication on language demands of science textbooks in the primary grades is included in a book edited by M. S. Khine entitled "Critical analysis of science textbooks: evaluating instructional effectiveness" (Springer).

Sara E. D. Wilmes is a doctoral candidate at the University of Luxembourg. Her research centers on communication in multilingual learning environments. In two of her past lives, she was a curriculum designer at the Science Education for Public Understanding Program (SEPUP), at the Lawrence Hall of Science, University of California, Berkeley, and a middle school science teacher in western New York.

Marissa Bellino is a doctoral candidate in the Urban Education Ph.D. program at The Graduate Center of the City University of New York and teaches a research methods course for pre-service and in-service teachers at Brooklyn College. Her research interests are focused on reimagining environmental education by utilizing critical theory and participatory research methods to interpret the lived experiences of urban youth. She taught in an urban public high school for over 10 years developing multiple science research courses. Marissa is also the co-founder and Director of Education and Outreach for The Biodiversity Center of Belize dedicated to developing Belizean human capital through STEM research and education. 